\title{
KEL wt Allele
}

National Cancer Institute

\section{Source}

National Cancer Institute. KEL wt Allele. NCI Thesaurus. Code C147985.

Human KEL wild-type allele is located in the vicinity of $7 q 34$ and is approximately $22 \mathrm{~kb}$ in length. This allele, which encodes Kell blood group glycoprotein, plays a role in peptide hormone-converting enzyme activity. Point mutations in the gene determine an individual's Kell blood group antigen profile. 